\title{
Ecophysiological responses of Quercus gilva, endangered species and $Q$. glauca to long-term exposure to elevated $\mathrm{CO}_{2}$ concentration and temperature
}

\author{
Hae-Ran Kim and Young-Han You* \\ Department of Biology, Kongju National University, Gongju 314-701, Korea
}

\begin{abstract}
The physiological effects of elevated $\mathrm{CO}_{2}$ concentration and temperature were examined for Quercus gilva and Q. glauca grown under control (ambient $\mathrm{CO}_{2}$ and temperature) and treatment (elevated $\mathrm{CO}_{2}$ and temperature) conditions for 39 months. The objective of the study was to measure the long-term responses, in physiological parameters, of two oaks species exposed to elevated $\mathrm{CO}_{2}$ and temperature. The photosynthetic rate of $Q$. gilva was found to be decreased, but that of Q. glauca was not significantly affected, after long-term exposure to elevated $\mathrm{CO}_{2}$ and temperature. Stomatal conductance of Q. glauca was reduced by $21.7 \%$, but that of $Q$. gilva was not significantly affected, by long-term exposure to $\mathrm{CO}_{2}$ and temperature. However, the transpiration rate of the two oak species decreased. Water use efficiency of Q. gilva was not significantly affected by elevated $\mathrm{CO}_{2}$ and temperature, while that of $Q$. glauca was increased by $56.6 \%$. The leaves of Q. gilva grown under treatment conditions had an increased C:N ratio due to their reduced nitrogen content, while those of Q. glauca were not significantly affected by long-term exposure to elevated $\mathrm{CO}_{2}$ and temperature. These results suggest that the long-term responses to elevated $\mathrm{CO}_{2}$ and temperature between Q. gilva and Q. glauca are different, and that $Q$. gilva, the endangered species, is more sensitive to elevated $\mathrm{CO}_{2}$ and temperature than Q. glauca.
\end{abstract}

Key words: endemic plants, evergreen broad-leaved, global climate change, leaf nitrogen, photosynthesis, Quercus

\section{INTRODUCTION}

Increased atmospheric $\mathrm{CO}_{2}$ concentrations associated with increasing temperatures can directly affect the growth and development of plants through the influence of their physiology. Thus, understanding the interactive effects of elevated $\mathrm{CO}_{2}$ and temperature on plant physiological responses is essential in order for accurate predictions of the effects of climate change to be made.

Much research over the past few decades has focused on the effects of rising atmospheric $\mathrm{CO}_{2}$ concentration and temperature on the physiology of woody plants (Zhou et al. 2011). In general, the short-term exposure of plants to high $\mathrm{CO}_{2}$ levels causes a significant increase in photosynthetic rates and decreases in stomatal conductance (Curtis 1996). However, many studies have shown that accelerated net carbon assimilation is not maintained over longer time periods, and a substantial decline in photosynthesis may occur after long-term exposure to elevated $\mathrm{CO}_{2}$ (DeLucia et al. 1985). Also, stomatal conductance may be increased or decreased, when plants are exposed to elevated $\mathrm{CO}_{2}$ concentrations and temperatures over long periods.

Short-term measurements of the effects of $\mathrm{CO}_{2}$ con-

\section{Open Access http://dx.doi.org/10.5141/JEFB.2012.025}

This is an Open Access article distributed under the terms of the Creative Commons Attribution Non-Commercial License (http://creativecommons org/licenses/by-nc/3.0/) which permits unrestricted non-commercial use distribution, and reproduction in any medium, provided the original work is properly cited.
Received 13 June 2012, Accepted 01 July 2012

*Corresponding Author

E-mail: youeco21@kongju.ac.kr

Tel: +82-41-850-8508 
centration on physiological responses of plants are not always good indicators of the effects of long-term exposure (Long et al. 2004). Sour orange grown at $+300 \mathrm{ppm} \mathrm{CO}_{2}$ above control condition showed that the enhancement ratio for net photosynthesis was about 2.8 in 2 year, but had declined to 1.3 by 14 year, indicating some acclimation to the elevated $\mathrm{CO}_{2}$ (Kimball and Idso 2005), while in a further similar study the photosynthetic rate of loblolly pine was shown to be increased in high $\mathrm{CO}_{2}$ levels during all four years (Tissue et al. 1997).

Woody plants have lower relative growth rates and are less responsive to elevated $\mathrm{CO}_{2}$ and temperature than herbaceous species. Also, woody species may be less functionally plastic to elevated $\mathrm{CO}_{2}$ than non-woody species (Nowak et al. 2004). Thus, it is necessary to conduct long-term experiments on the effects of elevated $\mathrm{CO}_{2}$ and temperature on the physiological responses of woody plants to obtain more significant data.

In long-term experiments, down-regulation of photosynthesis is often associated with the responses of leaf chemical compositions, such as leaf nitrogen and carbon contents, to elevated $\mathrm{CO}_{2}$ and temperature (Roumet et al. 2000). In one study, the leaves of seedlings exposed to elevated $\mathrm{CO}_{2}$ had lower concentrations of nitrogen than seedlings exposed to ambient conditions, and nitrogen levels declined by $25 \%$ in Alphitonia petriei and $29 \%$ in Flindersia brayleyana, respectively (Kanowski 2001). The C:N ratios of the Phytolacca insularis and P. americana grown at elevated $\mathrm{CO}_{2}$ and increased temperature were reduced by $24 \%$ and $7 \%$, respectively, as compared with the control plants (Kim and You 2010a).

The habitat ranges and growth rates of woody species can often be related to temperature (Walther 2002). In particular, evergreen broad-leaved species are considered to be limited by the length of the growing season and absolute minimum temperature (Walther et al. 2001). Peng et al. (2011) determined that if the air temperature increased by $2^{\circ} \mathrm{C}$ without changes in precipitation rates, the net primary productivity of evergreen broad-leaved forests would be increased by $5.5 \%$.

The evergreen broad-leaved forest is one of the main vegetation types in warm temperate regions of Korea. It occurs in the region south of $35^{\circ} \mathrm{N}$ and from $126^{\circ}$ to $128^{\circ}$ $\mathrm{E}$ (Koo et al. 2001). The potential habitats of the evergreen broad-leaved species should expand with increasing temperatures, and hence, it might be suggested that evergreen broad-leaved species could be used as indicators of climate change (Iversen 1944). Thus, for a variety of practical purposes, it is necessary to determine the responses of evergreen broad-leaved plant to elevated $\mathrm{CO}_{2}$ and high temperature.

In Korea, several studies have made on the influence of elevated $\mathrm{CO}_{2}$ and/or higher temperatures on the growth and physiological responses of crops and herbs, such as rice (Kim and You 2010b), meadow-grass (Hwangbo and Kwak 2001), cabbage and radish (Choi et al. 2011) as well as native and invasive plants (Kim and You 2010a, Shin et al. 2012), etc. However, within Korea there has been no such study that tried to determine the ecophysiological responses of evergreen woody species to elevated $\mathrm{CO}_{2}$ and temperature.

Quercus gilva and Q. glauca are evergreen broad-leaved oak species of the warm temperate regions of Korea. $Q$. glauca is scattered along the southern coasts and islands, but Q. gilva, designated as an endangered plant by the Korean Ministry of Environment, is limited to the lowland mountain regions of Jeju Island in Korea.

We investigated the effects of long-term exposure to elevated $\mathrm{CO}_{2}$ and increased temperature on these two evergreen broad-leaved oaks species, and measured the physiological responses, including photosynthetic rate, stomatal conductance, transpiration rate, water use efficiency (WUE), $\mathrm{N}$ and $\mathrm{C}$ content and C:N ratio of treatment and control groups. The objective of this study was to understand the long-term responses of Q. gilva and $Q$. galuca to increasing ambient $\mathrm{CO}_{2}$ and temperature.

\section{MATERIALS AND METHODS}

\section{$\mathrm{CO}_{2}$ treatments and experimental plants}

This study was conducted in glass greenhouse $(12 \mathrm{~m}$ length $\times 7.8 \mathrm{~m}$ width $\times 5 \mathrm{~m}$ height). The surface area of control and treatment is $46.8 \mathrm{~m}^{2}$ respectively. The control was maintained at ambient $\mathrm{CO}_{2}$ concentration, which averaged approximately $360 \pm 9.2 \mathrm{ppm}$ on a 24 -h basis (Fig. 1). Treatment with elevated $\mathrm{CO}_{2}$ concentration achieved by inputting a small quantity of pure $\mathrm{CO}_{2}$ through two perforated plastic hoses so as to maintain the concentration at approximately $742.30 \pm 16.92 \mathrm{ppm}$, twice that of the ambient $(360.38 \pm 9.19 \mathrm{ppm})$ concentration. $\mathrm{CO}_{2}$ concentration was monitored by a $\mathrm{CO}_{2}$ sensor (TEL-7001; Onset Computer, Bourne, MA, USA) at 30-min intervals, and data was stored on data-logger (HOBO U12; Onset Computer) to evaluate the stability of the $\mathrm{CO}_{2}$ concentration in the treatment. The $\mathrm{CO}_{2}$ treatment lasted from May 2008 to June 2011 (39 months).

The mean temperature in the treatment was about $2.5^{\circ} \mathrm{C}$ higher than the control (Fig. 1). The air temperature 

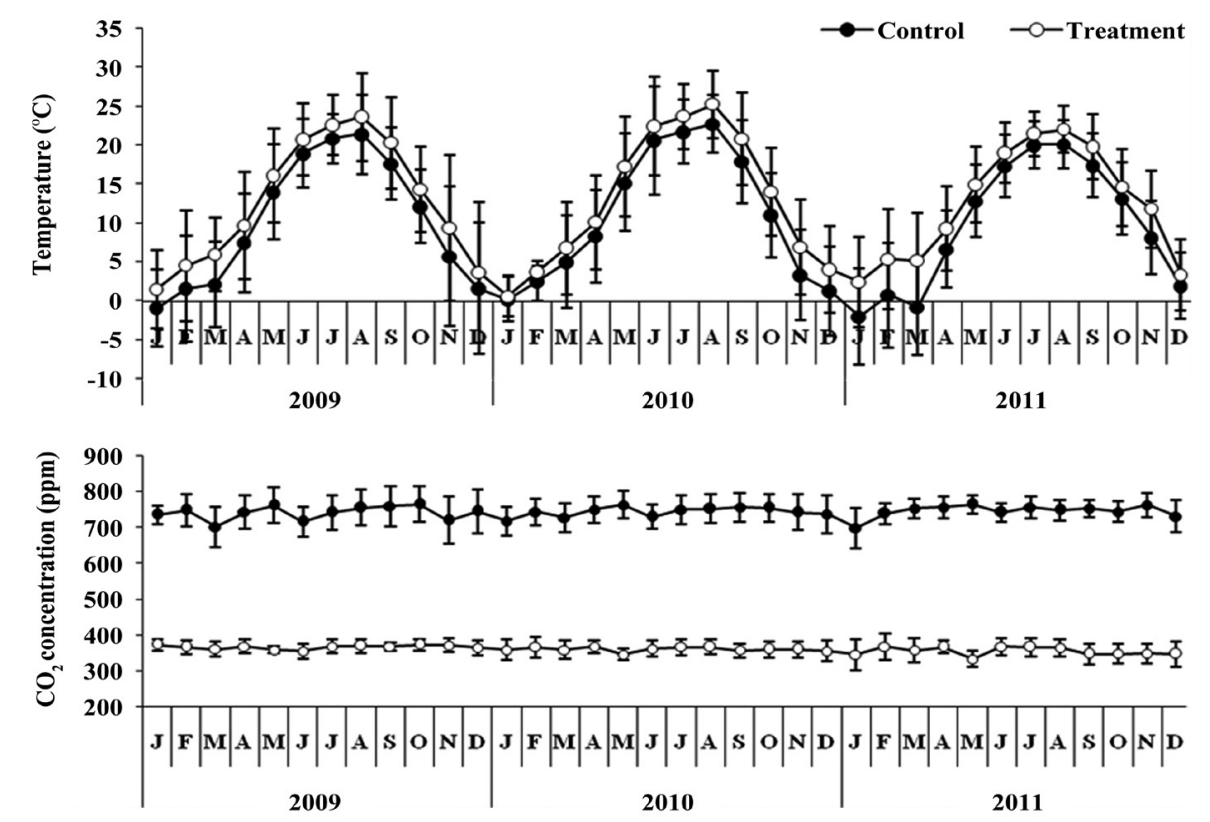

Fig. 1. Monthly mean values of air temperature and $\mathrm{CO}_{2}$ concentration in control and treatment greenhouses throughout the experimental period.

was measured using a thermo recorder (TR-71U; T\&D Co., Matsumoto, Japan) at the same height in the control and treatment greenhouses during the study period.

In March 2008, the seeds of two species were sown in pots (diameter $22.5 \mathrm{~cm}$, height $27 \mathrm{~cm}$ ) filled with equal volumes of sand, and we fertilized $0.5 \%$ of the sand weight. We subsequently applied organic fertilizer, which contains an ammonium nitrogen content below $170 \mathrm{mg} / \mathrm{L}$ and nitrate nitrogen at a concentration of 150-330 mg/L (Monsanto Korea Inc., Seoul, Korea). The plants were watered twice or three times per week to prevent them from suffering from water stress.

In January 2009, four seedlings of each species was transplanted into larger pots $(120 \mathrm{~cm} \times 85 \mathrm{~cm} \times 48 \mathrm{~cm})$ containing sand, in order to remove root growth restrictions.

\section{Gas-exchange measurements}

The photosynthetic characteristics of the treatment and control plants of the two species were measured at the vegetative stage, using an LCi Ultra Compact Photosynthesis System (Lci Pro; ADC Bioscientific, Hoddesdon, UK) from 10:00 am to 12:00 pm in June, 2009 and 2011.

Three fully expended leaves from the upper part of the plants, and the current year's growth, were selected from each of the four individuals. All measurements were replicated more than 10 times per leaf section.

The light source utilized natural light, and photosyn- thetic active radiation (PAR) was 400-600 $\mu$ mol PAR m ${ }^{-2}$ $\mathrm{s}^{-1}$. Relative humidity was $70.79 \pm 18.56 \%$ in the control greenhouse and $72.04 \pm 16.59 \%$ in the treatment greenhouse. There were no significant differences of PAR or relative humidity between control and treatment greenhouses.

The determined physiological parameters included photosynthetic rate $\left(\mu \mathrm{mol} \mathrm{m} \mathrm{m}^{-2} \mathrm{~s}^{-1}\right)$, stomatal conductance $\left(\mathrm{mol} \mathrm{m}^{-2} \mathrm{~s}^{-1}\right)$, transpiration rate $\left(\mathrm{mmol} \mathrm{m} \mathrm{m}^{-2} \mathrm{~s}^{-1}\right)$ and WUE $\left(\mu \mathrm{mol} \mathrm{CO}_{2} / \mathrm{mmol} \mathrm{H}_{2} \mathrm{O}\right.$ ). WUE was calculated as the ratio between photosynthesis rate and transpiration rate.

\section{Leaf C:N ratio, nitrogen and carbon contents}

The samples of leaves were dried for 2 days at $65^{\circ} \mathrm{C}$. After the leaves were dried, the samples were pulverized into fine powder with a blender (AKM-369s; Eupa, Seoul, Korea). The nitrogen and carbon contents were determined using an automatic elemental analyzer (Flash EA 1112 series; Thermo Fisher Scientific, Rochester, NY, USA) at the Center for Research Facilities, Chungnam National University. The C:N ratio was calculated as the ratio of carbon content to nitrogen content.

\section{Statistical analysis}

The determined effects of elevated $\mathrm{CO}_{2}$ and temperature on the physiological parameters of two oak species were confirmed via one-way ANOVA, and the statistical 


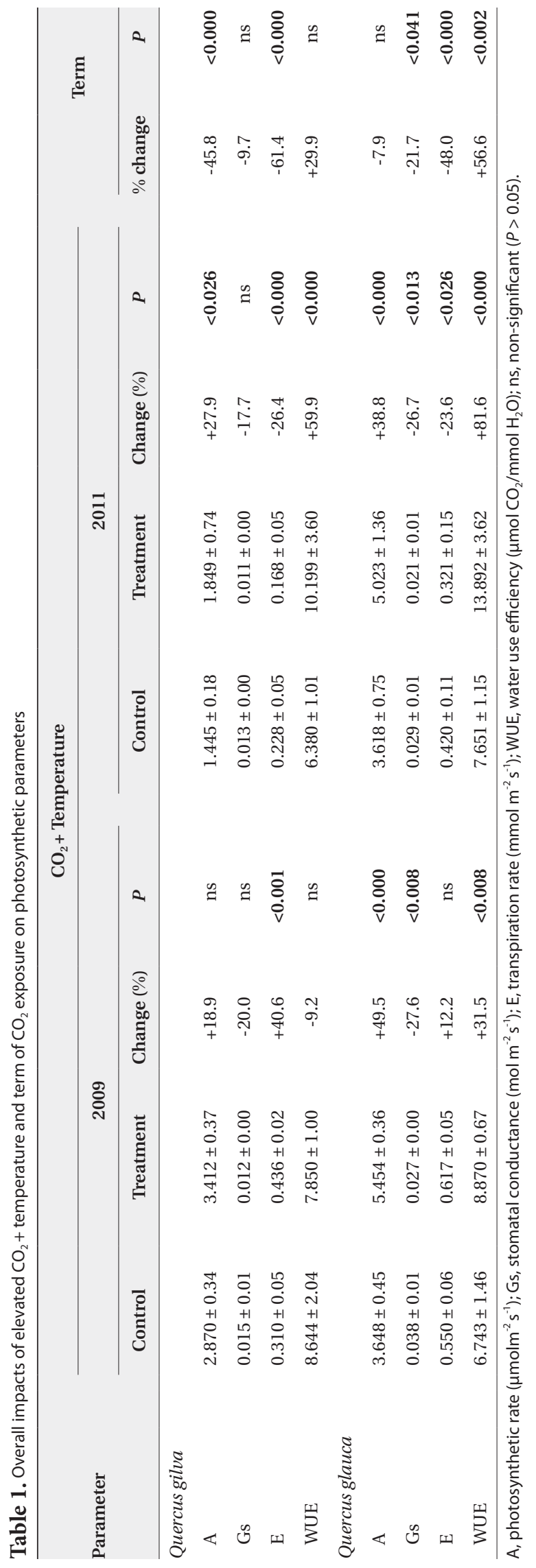

differences between the control and treatment groups were evaluated by Fisher's least significant difference test as post-hocs, with significance set at $P=0.05$. Multivariate analysis of variance (MANOVA) was used to analyze the effects of elevated $\mathrm{CO}_{2}$ concentration and temperature, species, term of exposure and their interaction within each species.

All statistical analyses were performed at a 0.05 level of confidence with STATISTICA 8 software (Statsoft, Inc., Tulsa, OK, USA).

\section{RESULTS}

\section{Effects of elevated $\mathrm{CO}_{2}$ and temperature on pho- tosynthetic responses}

Elevated $\mathrm{CO}_{2}$ and temperature stimulated the photosynthetic rate of both oak species in 2009 and 2011, although the difference in photosynthetic rates of Q. gilva in 2009 between control and treatment did not reach a significance level of $P<0.05$ (Tables 1 and 2). The percent stimulation of photosynthesis due to elevated $\mathrm{CO}_{2}$ and temperature for Q. glauca seedlings reached $49.5 \%$ and $38.8 \%$ in 2009 and 2011, respectively. The photosynthetic rate of Q. gilva was not significantly affected by elevated $\mathrm{CO}_{2}$ and temperature in 2009, but increased by $27.9 \%$ compared with the control in 2011.

Stomatal conductance was significantly reduced in $Q$. glauca grown under treatment conditions, but not in $Q$. gilva. The transpiration rate of Q. gilva was increased by $40.6 \%$, but that of Q. glauca was not significantly affected, by elevated $\mathrm{CO}_{2}$ and temperature in 2009. In contrast, transpiration rate of both oak species was significantly reduced compared with the controls in 2011.

WUE of Q. gilva was not significantly affected by elevated $\mathrm{CO}_{2}$ and temperature in 2009 but was increased by $59.9 \%$ compared with control in 2011. Elevated $\mathrm{CO}_{2}$ and higher temperatures resulted in a rise of $31.5 \%$ in WUE in 2009, and 81.6\% in 2011 in Q. glauca.

\section{Effects of terms of $\mathrm{CO}_{2}$ exposure on photosyn- thetic responses}

After long-term exposure to elevated $\mathrm{CO}_{2}$ and temperature, the photosynthetic rate of Q. gilva was decreased by $45.8 \%$, but that of Q. glauca was not significantly affected (Tables 1 and 2). Stomatal conductance of Q. glauca was reduced by $21.7 \%$, but that of Q. gilva was not significantly affected by long-term exposure to $\mathrm{CO}_{2}$ and temperature. 
Table 2. Effects of elevated $\mathrm{CO}_{2}+\mathrm{T}$ and term of $\mathrm{CO}_{2}$ exposure and their interactions on photosynthetic parameters of Quercus gilva and Q. glauca

\begin{tabular}{|c|c|c|c|c|c|c|c|c|}
\hline \multirow{2}{*}{ Factor } & \multicolumn{2}{|c|}{ A } & \multicolumn{2}{|c|}{ Gs } & \multicolumn{2}{|c|}{ E } & \multicolumn{2}{|c|}{ WUE } \\
\hline & $F$ & $P$ & $F$ & $P$ & $F$ & $P$ & $F$ & $P$ \\
\hline \multicolumn{9}{|l|}{ Quercus gilva } \\
\hline $\mathrm{CO}_{2}+\mathrm{T}(\mathrm{A})$ & 5.843 & $<0.020$ & 3.850 & ns & 5.180 & $<0.028$ & 1.231 & ns \\
\hline Term (B) & 58.311 & $<0.000$ & 1.351 & ns & 146.684 & $<0.000$ & 0.236 & ns \\
\hline $\mathrm{A} \times \mathrm{B}$ & 0.125 & ns & 0.012 & ns & 41.694 & $<0.000$ & 8.625 & $<0.005$ \\
\hline \multicolumn{9}{|c|}{ Quercus glauca } \\
\hline $\mathrm{CO}_{2}+\mathrm{T}(\mathrm{A})$ & 23.785 & $<0.000$ & 13.302 & $<0.000$ & 0.162 & ns & 35.283 & $<0.000$ \\
\hline Term (B) & 0.490 & ns & 11.638 & $<0.001$ & 28.607 & $<0.000$ & 20.090 & $<0.000$ \\
\hline$A \times B$ & 0.372 & ns & 0.281 & ns & 4.356 & $<0.043$ & 9.366 & $<0.004$ \\
\hline
\end{tabular}

A, photosynthetic rate $\left(\mu \mathrm{mol} \mathrm{m} \mathrm{m}^{-2} \mathrm{~s}^{-1}\right) ; \mathrm{Gs}$, stomatal conductance $\left(\mathrm{mol} \mathrm{m} \mathrm{s}^{-1}\right) ; \mathrm{E}$, transpiration rate $\left(\mathrm{mmol} \mathrm{m} \mathrm{s}^{-2}\right) ;$ WUE, water use efficiency $\left(\mu \mathrm{mol} \mathrm{CO}_{2} / \mathrm{mmol}^{-1}\right.$ $\left.\mathrm{H}_{2} \mathrm{O}\right)$; ns, non-significant $(P>0.05)$.

The transpiration rate of both oak species was largely decreased after long-term exposure to elevated $\mathrm{CO}_{2}$ and temperature. WUE of Q. gilva was not significantly affected by elevated $\mathrm{CO}_{2}$ and temperature, while that of $Q$. glauca was increased by $56.6 \%$.

\section{Effects of elevated $\mathrm{CO}_{2}$ and temperature on leaf $\mathrm{C}: \mathrm{N}$ ratio, nitrogen and carbon contents}

Elevated $\mathrm{CO}_{2}$ and temperature resulted in a decline in leaf nitrogen content for two oak species throughout this study (Table 3 and Fig. 2). The nitrogen content for Q. gilva under treatment decreased by $34 \%$ in 2009 and $36.4 \%$ in 2011, when compared to that of the control. For Q. glauca, the nitrogen content was found to be increased by $21.6 \%$ in 2009 , and $27.4 \%$ in 2011 , when compared to those grown in the control. The carbon content of Q. gil$v a$ was not found to be significantly affected by elevated $\mathrm{CO}_{2}$ and temperature in either 2009 or 2011 . However, within Q. glauca, elevated $\mathrm{CO}_{2}$ and temperature caused a significant increase in leaf carbon content in 2011 but not in 2009. C:N ratio increases due to elevated $\mathrm{CO}_{2}$ and temperature for Q. gilva and Q. glauca reached $52.5 \%$ and $57.3 \%$ in 2009 , and $22.3 \%$ and $42.3 \%$ in 2011 , respectively.

\section{Effects of term of $\mathrm{CO}_{2}$ exposure on leaf $\mathrm{C}: \mathrm{N}$ ratio, nitrogen and carbon contents}

The pooled data for Q. gilva showed significant term of exposure effects of nitrogen, carbon content and C:N ratio, although the difference in carbon content of seedlings grown at elevated $\mathrm{CO}_{2}$ and temperature between in 2009 and 2011 did not reach a significance level of $P<0.05$ (Table 3 and Fig. 2). After long-term exposure to elevated $\mathrm{CO}_{2}$ and temperature, the nitrogen content of Q. gilva declined by $10.1 \%$, with an associated C:N ratio increase of
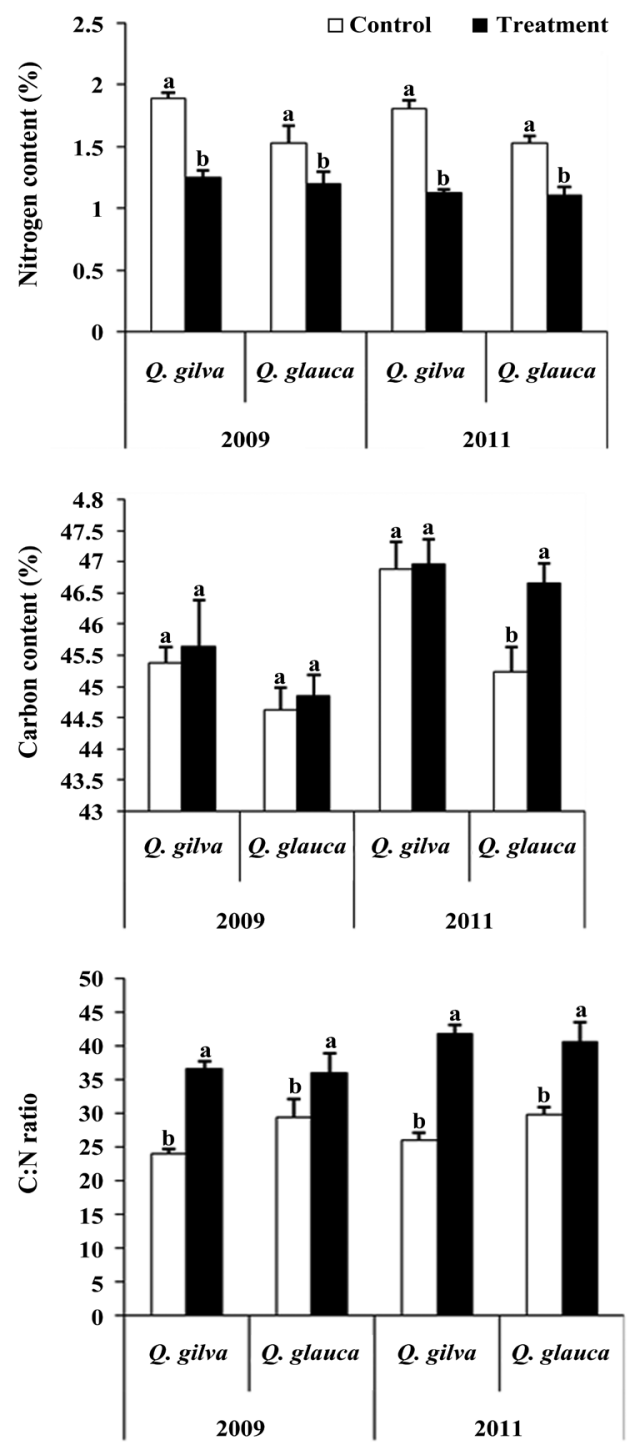

Fig. 2. Nitrogen content, carbon content and C:N ratio of Quercus gilva and $Q$. glauca grown under control and treatment conditions. Different lower cases on the bars indicate significant differences between control and treatment within each species (Fisher's least significant difference, $P<0.05)$. 


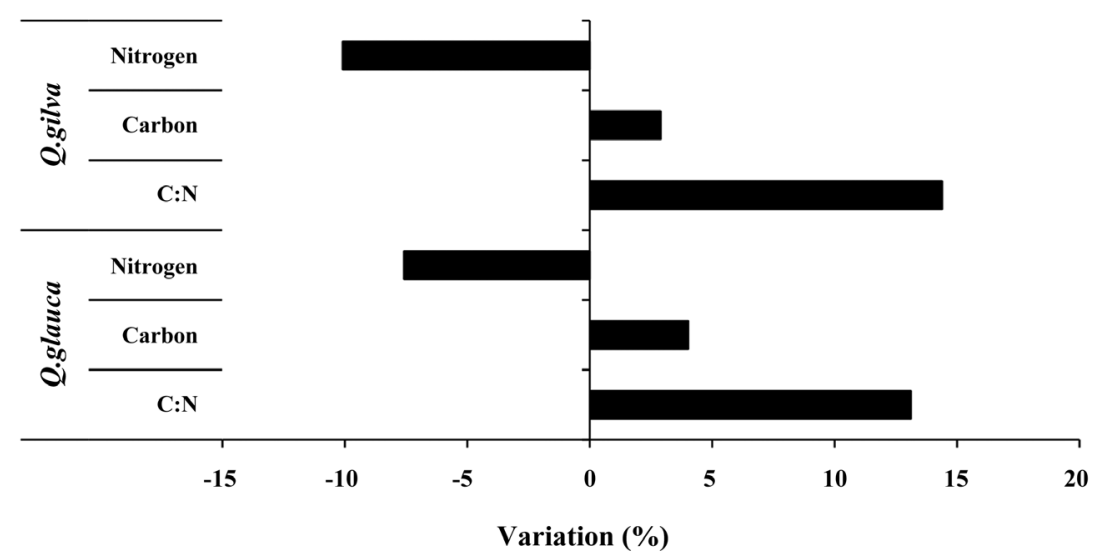

Fig. 3. Percentage variation of leaf nitrogen, carbon content and C:N ratio of Quercus gilva and Q. glauca. The change in percent for each parameter is calculated as the change in percent for measured values in 2011 compared to measured values in 2009, under the elevated $\mathrm{CO}_{2}$ and temperature.

\section{$14.4 \%$ (Fig. 3).}

For Q. glauca, however, the term of exposure effects only caused a significant increase in leaf carbon content, but not in nitrogen content and C:N ratio (Table 3 and Fig. 3 ). The leaf carbon content of Q. glauca was about $4 \%$ increased, but nitrogen content and C:N ratio was not significantly affected by long-term of exposure.

\section{DISCUSSION}

Down-regulation of photosynthesis was observed for Q. gilva after long-term of exposure to elevated $\mathrm{CO}_{2}$ and temperature (Table 1), similar to the general decreased investment in photosynthesis that has been seen in other species (DeLucia et al. 1985). According to Faria et al. (1996), the net photosynthetic rate of Q. suber seedlings grown at elevated $\mathrm{CO}_{2}$ concentration was $40 \%$ lower than for those grown at ambient $\mathrm{CO}_{2}$ concentrations. The $\mathrm{CO}_{2}$ induced enhancement of photosynthesis of $C$. aurantium was shown to have declined after 14 year of exposure to elevated $\mathrm{CO}_{2}$ (Adam et al. 2004) and photosynthetic down-regulation was reported for 1-year-old foliage of $P$. taeda trees exposed to elevated $\mathrm{CO}_{2}$ for 9 years (Crous et al. 2008).

The down-regulation of photosynthesis of plants grown in elevated $\mathrm{CO}_{2}$ and temperature is often associated with starch accumulation (Tissue et al. 1993), reduction in rubisco content and activity (Albert et al. 2011), acclimation of photosynthetic capacity, such as the maximum carboxylation rate and the maximum rate of electron transport (Ainsworth and Rogers 2007), and, in particular, with leaf $\mathrm{N}$ content (Chaturvedi et al. 2009).

Many researchers have reported changes in the nitro-

Table 3. Effects of elevated $\mathrm{CO}_{2}+\mathrm{T}$, term of $\mathrm{CO}_{2}$ exposure and their interactions on leaf nitrogen content, carbon content and C:N ratio for Quercus gilva and Q. glauca

\begin{tabular}{|c|c|c|c|c|c|c|}
\hline \multirow{2}{*}{ Factor } & \multicolumn{2}{|c|}{ Nitrogen content } & \multicolumn{2}{|c|}{ Carbon content } & \multicolumn{2}{|c|}{ C:N ratio } \\
\hline & $F$ & $P$ & $F$ & $P$ & $F$ & $P$ \\
\hline \multicolumn{7}{|l|}{ Quercus gilva } \\
\hline $\mathrm{CO}_{2}+\mathrm{T}(\mathrm{A})$ & 443.71 & $<0.000$ & 0.40 & ns & 489.63 & $<0.000$ \\
\hline Term (B) & 11.39 & $<0.010$ & 25.20 & $<0.001$ & 31.91 & $<0.000$ \\
\hline $\mathrm{A} \times \mathrm{B}$ & 0.39 & ns & 0.10 & ns & 6.46 & $<0.035$ \\
\hline \multicolumn{7}{|c|}{ Quercus glauca } \\
\hline $\mathrm{CO}_{2}+\mathrm{T}(\mathrm{A})$ & 46.885 & $<0.000$ & 16.80 & $<0.003$ & 48.49 & $<0.000$ \\
\hline Term (B) & 0.762 & ns & 35.40 & $<0.000$ & 2.80 & ns \\
\hline $\mathrm{A} \times \mathrm{B}$ & 0.623 & ns & 9.00 & $<0.017$ & 2.09 & ns \\
\hline
\end{tabular}

ns, non-significant $(P>0.05)$. 
gen contents of plant parts under such conditions (e.g., Cotrufo et al. 1998). The prolonged exposure to elevated $\mathrm{CO}_{2}$ concentration and temperature a leads to reduction in leaf nitrogen content associated with a down-regulation of photosynthesis (Kuehny et al. 1991). The strong relationship between net $\mathrm{CO}_{2}$ assimilation and leaf $\mathrm{N}$ based on mass is a principal functional relationship frequently utilized for predicting photosynthesis in many current models of plants at high $\mathrm{CO}_{2}$ levels (Liu et al. 2009) because the light capture, electron transport and the carbon metabolism portion of photosynthesis require large investments of nitrogen in the form proteins (Crous et al. 2010). According to Adam et al. (2004), the photosynthetic acclimation of $C$. aurantium has resulted in a reduced rubisco protein content relative to leaf $\mathrm{N}$ content after 14 years of exposure to elevated $\mathrm{CO}_{2}$ concentration.

We identified significant effects of elevated $\mathrm{CO}_{2}+\mathrm{T}$ and term of exposure on photosynthetic rates and leaf $\mathrm{N}$ contents of Q. gilva (Tables 2 and 3). The $\mathrm{CO}_{2}$ assimilation and leaf nitrogen content of Q. gilva were reduced by $45.8 \%$ and $7.9 \%$, respectively, after long-term exposure to elevated $\mathrm{CO}_{2}$ concentration and temperature (Table 1 and Fig. 3 ). Thus, the marked down-regulation of photosynthesis in seedlings of Q. gilva may be caused by reduction in leaf $\mathrm{N}$ content after long-term exposure to elevated $\mathrm{CO}_{2}$ and temperature.

The instantaneous photosynthetic rate of Q. gilva under treatment was greater than for those under control, despite the down-regulation of photosynthesis (Table 1). In this study, although the photosynthetic rate of Q. gilva was decreased by $45.8 \%$ after long-term exposure to elevated $\mathrm{CO}_{2}$ and temperature, it was higher in the treatment than in the control in 2009 and 2011 respectively (Table 1).

Unlike Q. gilva, Q. glauca seem to have different photosynthetic response to term of elevated $\mathrm{CO}_{2}$ and temperature exposure (Table 2). The photosynthetic rate of $Q$. glauca seedlings grown under treatment was higher than under control in 2009 and 2011, but there was no significant difference between short- and long-term of exposure to elevated $\mathrm{CO}_{2}$ and temperature (Table 1). According to Herrick and Thomas (2001), the net $\mathrm{CO}_{2}$ assimilation of Liquidambar styraciflua trees did not show down-regulation for 3 year. During the seventh year of exposure to elevated $\mathrm{CO}_{2}$ at the Duke free air $\mathrm{CO}_{2}$ enrichment (FACE) experiment, light-saturated net photosynthetic rates of the understory tree species were increased by elevated $\mathrm{CO}_{2}$, and showed no evidence of photosynthetic downregulation for any species (Springer and Thomas 2007).

One of the most consistent effects of growth at elevated $\mathrm{CO}_{2}$ is a decrease in stomatal conductance (Ainsworth and Rogers 2007), leading to decreased transpiration rate and improved WUE (Leakey et al. 2009).

Significant elevated $\mathrm{CO}_{2}+\mathrm{T}$ and term of exposure effects on stomatal conductance were detected in Q. glauca but not in Q. gilva (Table 2). The stomatal conductance in seedlings of Q. glauca decreased by $27.6 \%$ and $26.7 \%$ in 2009 and 2011, respectively, for those under treatment compared to the control, respectively. Besides, it determined that the long-term exposure of elevated $\mathrm{CO}_{2}$ and temperature significantly reduced stomatal conductance (Table 1). Tjoelker et al. (1998) determined that proportional declines in stomatal conductance in plants grown under elevated $\mathrm{CO}_{2}$ compared to ambient $\mathrm{CO}_{2}$ were about 25\% for Populus tremuloides, Larix laricina, and Picea mariana, and about $10 \%$ for Betula papyrifera and Pinus banksiana.

The pooled data of Q. glauca showed significant term of exposure effects on transpiration rate and WUE, as well as stomatal conductance (Table 2). After a long-term of exposure to elevated $\mathrm{CO}_{2}$ and temperature, the decline in stomatal conductance of Q. glauca caused a $48 \%$ reduction in transpiration rate and a $56.6 \%$ increase in WUE (Table 1). This improved WUE under elevated $\mathrm{CO}_{2}$ and temperature is likely due to lower stomatal conductance and transpiration, however, Q. gilva showed no such effects (Tables 1 and 2).

At the beginning of this study, elevated $\mathrm{CO}_{2}$ and temperature stimulated transpiration rates of both oak species, although, for Q. glauca, the difference in transpiration rate between treatment and control did not reach a significance level of $P<0.05$. In the 3 th year, the transpiration rate of Q. gilva and Q. glauca was reduced by $26.4 \%$ and $23.6 \%$, respectively (Table 1 ).

Higher temperatures increase transpiration and stomatal conductance by changing the vapor pressure deficit at the leaf surface. According to Valle et al. (1984), the transpiration of trees grown with high $\mathrm{CO}_{2}$ was similar that of ambient $\mathrm{CO}_{2}$ because the increases in leaf resistance caused by elevated $\mathrm{CO}_{2}$ were partially offset by increases in vapor pressure gradient between leaf surface and air, caused by increased transpiration. Also, stomatal conductance of the Yucca species was found to be increased under ambient $\mathrm{CO}_{2}$ when high temperature was applied $\left(>45^{\circ} \mathrm{C}\right)$ whereas those grown under elevated $\mathrm{CO}_{2}$ did not increase stomatal conductance when exposed to high temperatures (Huxman et al. 1998), and furthermore, elevated $\mathrm{CO}_{2}$ largely offset the interactive effects of high temperature on water relations and photosynthesis in seedlings of Larrea tridentata, an evergreen shrub (Smith et al. 1997). 


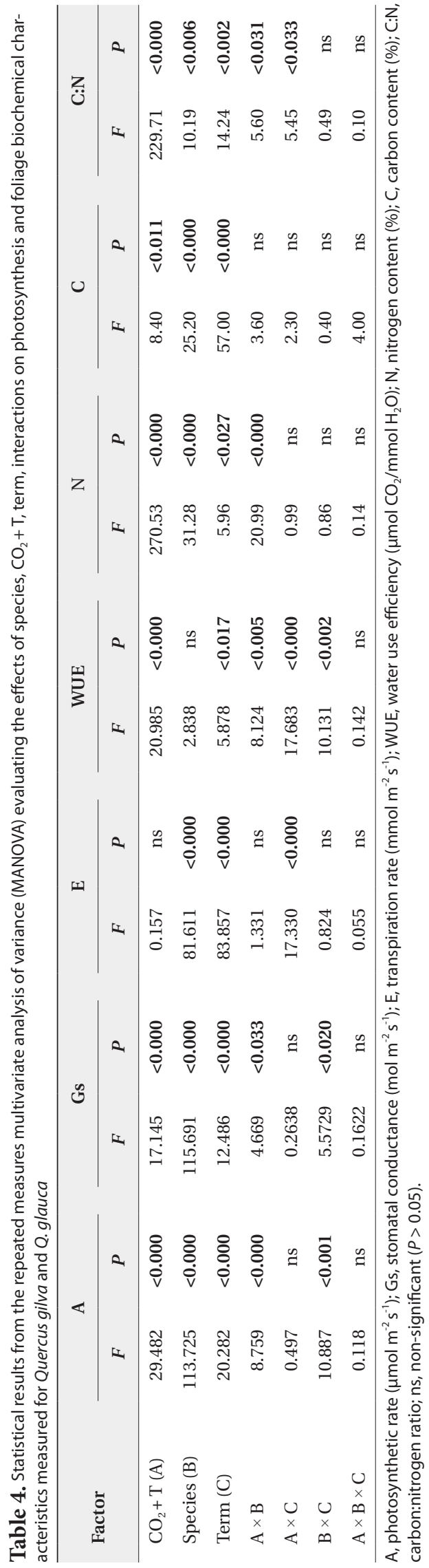

Our results suggest that two species, Q. gilva and $Q$. glauca, may respond more strongly to high temperature than to elevated $\mathrm{CO}_{2}$ concentration for the period of the experiment (1 year). However, after long-term exposure to elevated $\mathrm{CO}_{2}$ and temperature, elevated $\mathrm{CO}_{2}$ may largely offset the interactive effects of high temperature on stomatal conductance, transpiration and WUE.

A well known response of plants to elevated $\mathrm{CO}_{2}$ and temperature is the production of leaves with a higher C:N ratio. Increased C:N ratio is caused by a relative reduction of nitrogen content and/or an increase in carbon content (Curtis 1996). In our study, the leaves of Q. gilva had a reduced nitrogen content and high $\mathrm{C}: \mathrm{N}$ ratio after longterm exposure to elevated $\mathrm{CO}_{2}$ and temperature. Inauen et al. (2012) found that the C:N ratio of nine perennial plant species was increased by an average of $7 \%$ under elevated $\mathrm{CO}_{2}$ treatment, prescribing the enhanced C:N ratio as being mainly due to an overall $10 \%$ lower leaf nitrogen concentration.

Unlike Q. gilva, the nitrogen content and C:N ratio in leaves of $Q$. galuca was not significantly affected by elevated $\mathrm{CO}_{2}$ and temperature. Norby et al. (1999) reported varying results, ranging from a decrease of $35 \%$ to an increase of $20 \%$ for the leaves of trees grown in open-top chambers. This means that the effect of increased $\mathrm{CO}_{2}$ and temperature on leaf nitrogen content tends to be species-specific. Within our results, there were significant species-specific differences in the leaf nitrogen, as well as carbon content and C:N ratio of leaves.

Plant responses to elevated $\mathrm{CO}_{2}$ and temperature are generally species-specific. We found that $Q$. gilva and $Q$. glauca responded differently to elevated $\mathrm{CO}_{2}$ and temperature, and the responses of most physiological parameters were significantly different among each species (Table 4).

After long-term of exposure to elevated $\mathrm{CO}_{2}$ and temperature, no change in the photosynthetic rate of $Q$. glauca was observed, but the endangered plant, Q. gilva showed a photosynthetic down-regulation as well as a reduced leaf $\mathrm{N}$ content. The acquisition of carbon and energy through photosynthetic process is an important aspect of plant performance. Thus, if down-regulation of photosynthesis limits the ability to acquire carbon and energy, the growth and development of Q. gilva should be negatively impacted under future high- $\mathrm{CO}_{2}$ levels, whereas it is expected that the impact upon Q. glauca would be significantly less.

Unlike Q. gilva, the impoved water status of Q. glauca under elevated $\mathrm{CO}_{2}$ and temperature was likely due to increased WUE resulting from lower stomatal conduc- 
tance and transpiration. According to Parmesan and Yohe (2003), rare and endangered species with limited climatic ranges or restricted habitat requirements are generally less tolerant to environmental stresses, and have lower phenotypic plasticity in acclimation to a wider range of environmental conditions.

Thus, it is concluded that the Q. gilva, might respond more negatively to elevated $\mathrm{CO}_{2}$ concentrations and temperatures than $Q$. glauca, the non-endangered species. However, more long-term experiments and studies on mature trees under global climate changes is needed, as results obtained from saplings grown in elevated $\mathrm{CO}_{2}$ and temperature are unlikely to directly translate to mature trees.

\section{ACKNOWLEDGMENTS}

This research was supported by Basic Science Research Program through the National Research Foundation of Korea (NRF) funded by the Ministry of Education, Science and Technology (No. 2010-0006494).

\section{LITERATURE CITED}

Adam NR, Wall GW, Kimball BA, Idso SB, Webber AN. 2004. Photosynthetic down-regulation over long-term $\mathrm{CO}_{2}$ enrichment in leaves of sour orange (Citrus aurantium) trees. New Phytol 163: 341-347.

Ainsworth EA, Rogers A. 2007. The response of photosynthesis and stomatal conductance to rising $\left[\mathrm{CO}_{2}\right]$ : mechanisms and environmental interactions. Plant Cell Environ 30: 258-270.

Albert KR, Mikkelsen TN, Michelsen A, Ro-Poulsen H, van der Linden L. 2011. Interactive effects of drought, elevated $\mathrm{CO}_{2}$ and warming on photosynthetic capacity and photosystem performance in temperate heath plants. J Plant Physiol 68: 1550-1561.

Chaturvedi AK, Vashistha RK, Rawat N, Prasad P, Nautiyal MC. 2009. Effect of $\mathrm{CO}_{2}$ enrichment on photosynthetic behavior of Podophyllum hexandrum Royle, an endangered medicinal herb. J Am Sci 5: 113-118.

Choi EY, Seo TC, Lee SG, Cho IH, Stangoulis J. 2011. Growth and physiological responses of Chinese cabbage and radish to long-term exposure to elevated carbon dioxide and temperature. Hortic Environ Biotechnol 52: 376386.

Cotrufo MF, Ineson P, Scott A. 1998. Elevated $\mathrm{CO}_{2}$ reduces the nitrogen concentration of plant tissues. Glob Chang
Biol 4: 43-54.

Crous KY, Reich PB, Hunter MD, Ellsworth DS. 2010. Maintenance of leaf $\mathrm{N}$ controls the photosynthetic $\mathrm{CO}_{2}$ response of grassland species exposed to 9 years of free-air $\mathrm{CO}_{2}$ enrichment. Glob Chang Biol 16: 2076-2088.

Crous KY, Walters MB, Ellsworth DS. 2008. Elevated $\mathrm{CO}_{2}$ concentration affects leaf photosynthesis-nitrogen relationships in Pinus taeda over nine years in FACE. Tree Physiol 28:607-614.

Curtis PS. 1996. A meta-analysis of leaf gas exchange and nitrogen in trees grown under elevated carbon dioxide. Plant Cell Environ 19: 127-137.

DeLucia EH, Sasek TW, Strain BR. 1985. Photosynthetic inhibition after long-term exposure to elevated levels of atmospheric carbon dioxide. Photosynth Res 7: 175-184.

Faria T, Wilkins D, Besford RT, Vaz M, Pereira JS, Chaves MM. 1996. Growth at elevated $\mathrm{CO}_{2}$ leads to down-regulation of photosynthesis and altered response to high temperature in Quercus suber L. seedlings. J Exp Bot 47: 1755-1761.

Herrick JD, Thomas RB. 2001. No photosynthetic down-regulation in sweetgum trees (Liquidambar styraciflua $\mathrm{L}$.) after three years of $\mathrm{CO}_{2}$ enrichment at the Duke Forest FACE experiment. Plant Cell Environ 24: 53-64.

Huxman TE, Hamerlynck EP, Loik ME, Smith SD. 1998. Gas exchange and chlorophyll fluorescence responses of three south-western Yucca species to elevated $\mathrm{CO}_{2}$ and high temperature. Plant cell Environ 21: 1275-1283.

Hwangbo JK, Kwak YS. 2001. Effects of elevated $\mathrm{CO}_{2}$ and nitrogen on growth of Poa pratensis (L.). J Plant Biol 44: 12-16.

Inauen N, Körner C, Hiltbrunner E. 2012. No growth stimulation by $\mathrm{CO}_{2}$ enrichment in alpine glacier forefield plants. Glob Chang Biol 18: 985-999.

Iversen J. 1944. Viscum, Hedera and Ilex as climate indicators. Geol Foren Stockholm Forh 66: 463-483.

Kanowski J. 2001. Effects of elevated $\mathrm{CO}_{2}$ on the foliar chemistry of seedlings of two rainforest trees from north-east Australia: implications for folivorous marsupials. Austral Ecol 26: 165-172.

Kim HR, You YH. 2010a. Effects of elevated $\mathrm{CO}_{2}$ concentration and increased temperature on leaf related-physiological responses of Phytolacca insularis (native species) and Phytolacca americana (invasive species). J Ecol Field Biol 33: 195-204.

Kim HR, You YH. 2010b. The effects of the elevated $\mathrm{CO}_{2}$ concentration and increased temperature on growth, yield and physiological responses of rice (Oryza sativa L. cv. Junam). Adv Biores 1: 46-50.

Kimball BA, Idso SB. 2005. Long-term effects of elevated $\mathrm{CO}_{2}$ 
on sour orange trees. In: Plant Responses to Air Pollution and Global Change (Omasa K, Nouchi I, De Kok LJ, eds). Springer, Tokyo, pp 73-80.

Koo KA, Kong WS, Kim CK. 2001. Distribution of evergreen broad-leaved plants and climatic factors. J Korean Geogr Soc 36: 247-257. (in Korean)

Kuehny JS, Peet MM, Nelson PV, Willits DH. 1991. Nutrient dilution by starch in $\mathrm{CO}_{2}$-enriched Chrysanthemum. J Exp Bot 42: 711-716.

Leakey ADB, Ainsworth EA, Bernacchi CJ, Rogers A, Long SP, Ort DR. 2009. Elevated $\mathrm{CO}_{2}$ effects on plant carbon, nitrogen, and water relations: six important lessons from FACE. J Exp Bot 60: 2859-2876.

Liu F, Zhang M, Wang W, Chen S, Zheng J, Yang W, Hu F, An S. 2009. Photosynthesis in relation to leaf nitrogen, phosphorus and specific leaf area of seedlings and saplings in tropical montane rain forests of Hainan Island, south China. Front For China 4: 75-84.

Long SP, Ainsworth EA, Rogers A, Ort DR. 2004. Rising atmospheric carbon dioxide: plants FACE the future. Annu Rev Plant Biol 55: 591-628.

Norby RJ, Wullschleger SD, Gunderson CA, Johnson DW, Ceulemans R. 1999. Tree responses to rising $\mathrm{CO}_{2}$ in field experiments: implications for the future forest. Plant Cell Environ 22: 683-714.

Nowak RS, Ellsworth DS, Smith SD. 2004. Functional responses of plants to elevated atmospheric $\mathrm{CO}_{2}$ : do photosynthetic and productivity data from FACE experiments support early predictions? New Phytol 162: 253-280.

Parmesan C, Yohe G. 2003. A globally coherent fingerprint of climate change impacts across natural systems. Nature 421: 37-42.

Peng SL, You WH, Zeng ZM, Wang LY. 2011. Effects of recent 60 years climate change on net primary productivity of evergreen broad-leaved forest in Tiantong region of Zhejiang Province. Chin J Ecol 30: 502-507.

Roumet C, Garnier E, Suzor H, Salager JL, Roy J. 2000. Short and long-term responses of whole-plant gas exchange to elevated $\mathrm{CO}_{2}$ in four herbaceous species. Environ Exp Bot 43: 155-169.
Shin DH, Kim HR, You YH. 2012. Effects of elevated $\mathrm{CO}_{2}$ concentration and increased temperature on the change of the phenological and reproductive characteristics of Phytolocca insularis, a Korea endemic plant. J Wet Res 14: 1-9.

Smith SD, Monson RK, Anderson JE. 1997. Physiological Ecology of North American Desert Plants. Springer-Verlag, Berlin.

Springer CJ, Thomas RB. 2007. Photosynthetic responses of forest understory tree species to long-term exposure to elevated carbon carbon dioxide concentration at the Duke Forest FACE experiment. Tree Physiol 27: 25-32.

Tissue DT, Thomas RB, Strain BR. 1993. Long-term effects of elevated $\mathrm{CO}_{2}$, and nutrients on photosynthesis and rubisco in loblolly pine seedlings. Plant Cell Environ 16: 859-865.

Tissue DT, Thomas RB, Strain BR. 1997. Atmospheric $\mathrm{CO}_{2}$ enrichment increases growth and photosynthesis of Pinus taeda: a 4 year experiment in the field. Plant cell Environ 20: 1123-1134.

Tjoelker MG, Oleksyn J, Reich PB. 1998. Seedlings of five boreal tree species differ in acclimation of net photosynthesis to elevated $\mathrm{CO}_{2}$ and temperature. Tree Physiol 18: 715-726.

Valle R, Mishoe JW, Jones JW, Allen LH. 1984. Transpiration rate and water use efficiency of soybean leaves adapted to different $\mathrm{CO}_{2}$ environments. Crop Sci 25: 477-482.

Walther GR. 2002. Weakening of climatic constraints with global warming and its consequences for evergreen broad-leaved species. Folia Geobot 37: 129-139.

Walther GR, Carraro G, Klötzli F. 2001. Evergreen broadleaved species as indicators for climate change. In: "Fingerprints" of Climate Change: Adapted Behaviour and Shifting Species Ranges (Walther GR, Burga CA, Edwards PJ, eds). Kluwer Academic Plenum Publishers, New York, pp 151-162.

Zhou YM, Wang CG, Han SJ, Cheng XB, Li MH, Fan AN, Wang XX. 2011. Species-specific and needle age-related responses of photosynthesis in two Pinus species to longterm exposure to elevated $\mathrm{CO}_{2}$ concentration. Trees 25 : 163-173. 